\title{
15
}

\section{Developing New Faculty: An Evolving Program}

\section{Gloria Pierce}

Montclair State University

This essay describes the evolution of a program for the development of newe faculty at a public teaching university. The year-long process of orienting the newest professors to the campus and assisting them with their scholarship and teaching results in additional (albeit unplanned and unexpected) benefits, such as professional renewal of senior faculty who serve as advisors and entanced functioning of the university itself. Vital to the program's success is the productive involvement of key campus constituencies and responsiveness to feedback.

\section{INTRODUCTION}

66 Twish this program existed when I joined the faculty at MSU!" Senior 1 professors at a public university often repeat this refrain when they begin to realize the nature of the new faculty program that was instituted there six years ago. Their wistful remarks testify to the success of a faculty development program mandated for all newly hired tenure track faculty since 1994 at Montclair State University (MSU). At that time, the University embraced the expanded definition of scholarship advanced by Ernest Boyer (1990) by creating the Faculty Scholarship Incentive Program (FSIP) that offers all faculty the opportunity to engage in a scholarly project as an alternative to a full teaching assignment. Newly hired faculty participate by attending a two-hour session each week of their first academic year at MSU. Five senior faculty members (one from each college or school of the university) serve as advisors to the incoming cohort, helping them to become oriented to the university, establish a research agenda, and develop excellent teaching skills. 


\section{RATIONALE}

The rationale for the New Faculty Program (NFP) is strongly rooted in an organization development perspective that values human talent and considers its nurturance to be a major role of management (Gibb, 1978). The program itself demonstrates the commitment of the university's administration and professoriate to several principles that undergird a strong academic institution. First, a university's greatest strength resides in the quality of its faculty which is reflected in the quality of education delivered to students and in productive scholarship, as broadly defined by Boyer (1990). Second, it makes organizational sense to assist the newest faculty with the daunting tasks of acclimating to a new institution (and sometimes a new geographical area, as well), preparing courses, teaching effectively, and maintaining their scholarly activities (Boice, 1992). Third, constructive retention of faculty is mutually beneficial. Alignment of individual needs and values with organizational goals and culture produces high levels of faculty performance and satisfaction as well as institutional excellence (Rausch, 1984). If a good fit cannot be made, however, it is better for both to find out sooner rather than later.

\section{STRUCTURE}

The New Faculty Program operates under the auspices of the provost/ vice president for academic affairs and is administered directly by the office of the assistant vice president for academic affairs. As chief administrative officer of the division of academic affairs, the provost/VPAA oversees its three colleges, three schools, and several other academic centers and programs. The NFP Director, who reports to the assistant VPAA, is a professor with a background in organizational development, counseling, and adult education. She is responsible for recruiting and managing the five advisors (also referred to as mentors or resource faculty), for designing and developing the program, and for facilitating the weekly sessions. Because the resource faculty play such a vital role, their selection is a crucial responsibility of the director, in consultation with the assistant VPAA.

\section{Resource Faculty}

The resource faculty agree to serve for one year and receive a stipend equal to the compensation for a three-credit course each semester. Several have continued for more than one year, however, because there is no restriction on length of service, and some continuity is desirable. Advi- 
sors attend and help to facilitate the weekly group sessions and may spend another hour each week providing guidance on an individual basis. For these duties, they need excellent group process and interpersonal skills and a willingness to share their wealth of experience and knowledge about academic life and the culture of the university. Members of past cohorts appreciate the individual attention given to them, although not all junior faculty are receptive to the greater intensity of a one-on-one relationship. Some seek the counseling and psychological support of a mentor, while others require and request support that is more instrumental in nature, such as assistance in locating funding sources for research, grant-writing, or guidance about committee service. Hence, advisors are a resource for new faculty, providing assistance across the spectrum of developmental relationships (Kram, 1985). Originally, each mentor was assigned several proteges, a feature of the program that felt inauthentic. New faculty now have the opportunity to request various kinds of help from any of the advisors, as needed-a much more fluid process that seems to be more natural and comfortable for both.

\section{Weekly Sessions}

The first semester is front-loaded with nuts and bolts information about various support services that new faculty are likely to use (see Appendix 15.1). Recently, this orientation has taken the form of a poster session where new faculty can meet and speak with representatives from units such as the academic success center, which provides services related to student advisement, psychological counseling, service learning, students with disabilities, career development, tutorials, basic skills, etc. The poster session is another example of a modification made in response to previous cohorts' requests for an alternative to what they experienced as a parade of presenters each week. The new format has proven to be a more casual and lively occasion where faculty can choose to spend as much time as they wish at any particular display. Similarly, feedback from participants led to an expansion of the library orientation, which now provides more assistance in the use of library resources for research projects.

During the second semester, the focus shifts to more substantive considerations. At this point, the cohort has learned the essentials of the university environment and turns its attention to teaching and learning issues and further planning of research agendas (see Appendix 15.2). Representatives from the office of research and sponsored programs join the resource faculty in conducting seminars on preparing grant proposals both for external funding sources and for internally sponsored programs. The 
weekly sessions become more seminar-like in character and address matters of curriculum development, instructional methods, assessment and grading, and diversity. New faculty are pleased to take a more active role, preparing and presenting sessions on topics of their choice.

\section{Key Elements}

The NFP was developed in the context of a university with established resources and the administrative leadership to use them wisely. Five major components form the foundation of the program: 1) effective lateral and vertical feedback and communication processes; 2) administrative vision, commitment, and cooperation; 3 ) senior faculty's ability to provide mentorship and advisement to junior faculty; 4) senior faculty's skill and experience with professional development and effective educational practices; and 5) two specialized units created to assist faculty with all aspects of their teaching role-the Institute for Critical Thinking and the Center of Pedagogy.

\section{Feedback Loops}

Effective communication processes have been a hallmark of the New Faculty Program and are essential to its success. Continuous quality improvement (Deming, 1982, 1986, 1993) is achieved in several ways: 1) by soliciting written formative evaluations from the cohort of new faculty at the end of the first semester; 2) by written summative evaluations from them at the end of their academic year; 3 ) by informal feedback at the weekly seminars; 4) by regular assessment and consultation among the NFP director, the resource faculty, the assistant vice president for academic affairs and the provost/vice president for academic affairs; and 5) by an open line of communication between the director and other stakeholder constituencies on campus, such as deans, department chairs or other administrative divisions. The open flow of information and ideas allows problems to be encountered and remedied quickly. Yearly improvement results in a dynamic, evolving program that is highly responsive to the needs of new faculty and the campus community.

\section{Administrative Support}

The involvement of several levels of administration affects the NFP in various ways. Foremost is the leadership of the provost and staff in the office of academic affairs in providing the resources and attention necessary to operate the program. Administrative support is shown financially 
at a cost of approximately $\$ 350,000$ per year for a cohort of 20 new hires. This figure accounts for $25 \%$ of their salary, the stipend paid to resource faculty, release time for the director, refreshments, books, duplicating costs, and secretarial/clerical services.

Academic deans play an important role in several ways. First, they enlist the cooperation of department chairs who must schedule new professors' classes to allow them to attend NFP seminars. The two deans who co-authored the FSIP agreement with the faculty union remain especially committed to the NFP, each of them spending one full session with every incoming cohort to address contractual matters and FSIP procedures.

The attitude of department chairs and deans can have a chilling or salubrious effect on how new faculty view the NFP. Their support is needed, therefore, to point out the value of the program and to encourage the new members of their department to participate. The cooperation of other divisions on campus is necessary to inform new faculty about their services and how to access them. To sum up, the involvement of administrative personnel-deans, chairs, and division heads-is an integral part of the program.

\section{Role of Senior Faculty}

The five tenured professors who act as mentors are, unquestionably, the lifeblood of the program, developing the closest relationships with the cohort because of their active presence throughout the year. In the public forum of the weekly sessions, the five advisors work as a team to guide new faculty through the wide range of tasks they must perform, from academic advisement of students to preparation of reappointment applications and FSIP proposals.

In addition to facilitating plenary group discussions, advisors work with self-selected sub-groups as they develop sessions to be presented during the second semester. Cohorts decide upon presentation topics according to their concerns and their perceptions of current problems and issues in teaching and learning: "Teaching with sensitivity to diversity," "Using technology in instruction," "Teaching graduate students," and "The teacher-scholar in the teaching university."

University politics (i.e., the operation of the informal or hidden organization) is another area where senior faculty deal with the concerns of new faculty. Advisors find it can be difficult to give candid assessments about certain issues without causing undue consternation about reappointment, tenure, and promotion. Most senior faculty prefer to accentuate the positive aspects of campus culture lest they ignite negative 
expectations or fuel undue fears. Junior faculty, however, urge their mentors to be brutally honest about any pitfalls they may encounter. For example, participants from past cohorts have commented that they wanted the resource faculty to guide them through the rocks and shoals of institutional politics and to interpret for them the meaning of seemingly trivial issues that are laden with significance because of past events.

Advisors also act as moderators of a board game (Bollin \& Hill, 1996) played by teams of new faculty in which they are challenged to reflect on various aspects of teaching and learning and to share their experiences and insights with the group. The lively discussions stimulated by the game's questions require the advisors to use their skills in group work to keep the discussion on track, to keep the process moving, and to encourage reticent members of the group to participate.

Resource faculty must model effective group facilitation and instructional methods for two important reasons. First, the success of the cohort itself depends largely upon on the development of a healthy group. Second, modeling is important because of its transferability to the classrooms of new faculty. Many sessions of the NFP advocate best practices in teaching and learning such as student engagement, caring pedagogy, a safe learning environment, etc. If the content of the sessions becomes incongruent with the process (what individuals are actually experiencing), however, dissonance is created that contaminates the message and compromises learning goals (Argyris \& Schon, 1974). Unfortunately, the first cohort suffered from these discrepancies and from insufficient processing of their learning experience. Subsequently, the director made certain to choose advisors who would model best practices, who are attuned to the affective and maintenance needs of the group (Gladding, 1995) and who are capable of facilitating productive interactions. Increased attention to group process, therefore, is another significant change in the NFP since its inception.

\section{Support from Special Units}

The NFP draws heavily on the services of two special units that are well established at the university. The mission of the Institute for Critical Thinking is to foster critical thinking across the disciplines. Institute fellows are faculty from academic departments throughout the university who are committed to fostering critical thinking skills and dispositions in their students. As seminar leaders, they show new faculty how to infuse critical thinking into the curriculum and demonstrate instructional methods that foster critical thinking (Meyers, 1988). Practica in areas as diverse 
as music, broadcasting and the media, writing, philosophy for children, history, chemistry, biology, art, economics, marketing, and computer technology have enriched the program immensely.

Initially delivered during the fall semester, the critical thinking seminars became a source of stress for the first cohort of new faculty who felt overwhelmed by their breadth and depth and suggested that they be scheduled later in the year. Thus, the emphasis on critical thinking now occurs during the spring semester, after the new faculty have had a chance to get their bearings.

The Center of Pedagogy is another source of assistance from within the institution. The philosophy of the center is based on the work of John Goodlad $(1990,1994)$ and other prominent educators (Giroux, 1983, 1988; Noddings, 1995; Paul,1990; Greene, 1986, 1988; Freire, 1973, 1985; Brookfield, 1988, 1990). Its mission is to prepare students for participation in a social and political democracy and to encourage the use of best practices in pedagogy. Faculty affiliated with the center design activities to introduce new professors to principles such as caring pedagogy (Noddings 1995), and innovative methods to enhance their teaching, such as peer observation and coaching (Showers, 1984).

\section{ResulTs}

The NFP has produced unintended positive outcomes as well as met its stated objectives. Benefits accrue to three groups-junior faculty, senior faculty, and the university itself-and occur in three arenas-the classroom, the campus, and careers (gains in academe). These intersect with one another, producing nine categories of results, as shown in Table 15.1.

\section{New Faculty}

Because of the emphasis on teaching and learning, one would expect the NFP to have a substantial impact on curriculum, classroom climate, and delivery of instruction. New faculty attest to the aphorism "confidence breeds competence" (Fullan, 1993, p. 113) when they report feeling more self-assured about preparing syllabi, learning activities, tests, and assessing student work. Also, they are secure in the knowledge that help is available should questions or problems arise. Furthermore, junior faculty believe that the care shown to them by their advisors has made them more caring toward their students and more able to create a classroom climate conducive to learning. Thus, effects of the program extend to the students of new faculty. 
TABIF: 15.1

Outcomes of New Faculty Program

\begin{tabular}{|c|c|c|c|}
\hline & Classroom & Campus & Career \\
\hline $\begin{array}{l}\text { New } \\
\text { faculty }\end{array}$ & $\begin{array}{l}\text { - Caring pedagogy } \\
\text { - Critical thinking } \\
\text { - Student engagement }\end{array}$ & $\begin{array}{l}\text { - Integrated into univer- } \\
\text { sity } \\
\text { - Knowledge of services } \\
\text { - Stress reduction }\end{array}$ & $\begin{array}{l}\text { - Plan research } \\
\text { agenda } \\
\text { - Continue schol- } \\
\text { arship } \\
\text { - Professional de- } \\
\text { velopment }\end{array}$ \\
\hline $\begin{array}{l}\text { Senior } \\
\text { faculty }\end{array}$ & $\begin{array}{l}\text { - New instructional } \\
\text { methods } \\
\text { - Reflective of practice } \\
\text { - Deepened knowledge } \\
\text { of pedagogy }\end{array}$ & $\begin{array}{l}\text { - More appreciated } \\
\text { - More influential } \\
\text { - More isolated }\end{array}$ & $\begin{array}{l}\text { - Rejuvenation as } \\
\text { scholars } \\
\text { - Impetus to re- } \\
\text { sume research } \\
\text { - Professional de- } \\
\text { velopment }\end{array}$ \\
\hline University & $\begin{array}{l}\text { - Reputation for teach- } \\
\text { ing excellence } \\
\text { - High achieving stu- } \\
\text { dents } \\
\text { - Better retention rates }\end{array}$ & $\begin{array}{l}\text { - Increased productivity } \\
\text { of junior and senior } \\
\text { faculty } \\
\text { - Enhanced lateral and } \\
\text { vertical communica- } \\
\text { tion } \\
\text { - Improved procedures } \\
\text { - Humanization of cul- } \\
\text { ture }\end{array}$ & $\begin{array}{l}\text { Recognition for } \\
\text { leadership in } \\
\text { higher educa- } \\
\text { tion }\end{array}$ \\
\hline
\end{tabular}

NFP participants also gain a sense of connection and importance to the campus community. As a member of one cohort put it, "I never expected to feel so much a part of the university so quickly. Our group likes to joke about having our own hybrid theme song: 'You've got a friend . . . here, there, and everywhere.'" In general, comments made by new faculty indicate that they perceive the campus environment as welcoming and friendly, although there are pockets where friction exists. Thus, the program achieves a major goal-integration of new faculty into the university community.

By the time the program ends, the cohort has begun to plan and implement a scholarly agenda. They have learned how to access funding sources for their research and professional development. Many NFP participants already have received external grants and most are taking part in the FSIP or another internally sponsored research program. 


\section{Senior Faculty}

Professional development of the seasoned faculty who were asked to become mentors was not an explicit goal of the NFP. Nevertheless, professors who became involved found it an enriching experience and were rejuvenated in significant ways. Some reported that the NFP supplied the impetus to resume research projects that had been languishing. Others felt fortunate to have the opportunity to reflect on their teaching (Schon, 1983) and became enthusiastic about new approaches to learning in their classrooms. "It's so seldom that we actually get the chance to contemplate our teaching practices and to discuss what we do and how we feel about things in a safe environment. This year with the new people has been a real blessing," remarked one of the resource people.

The experience of veteran faculty parallels that of their protégés in that they too feel more included in university life and more able to function effectively within it. Some claim to be energized by their ability to make a significant contribution and to influence the university culture in positive directions (Wunsch, 1994), as this comment reveals: "The best part (of the NFP) for me was getting close to what's going on here. The idea of being influential is pretty compelling. Plus, it's really invigorating to know I'm doing something so worthwhile and that it's truly appreciated and valued."

Other instances further illustrate the convergence of individual with institutional renewal. Because of linkages made in the course of NFP events, several advisors formed collaborative relationships with colleagues. One such partnership resulted in a highly respected program in the School of the Arts. Such scholarly projects bring prestige to the university and help to alleviate the isolation that threatens to become an occupational hazard of the professorate (Fullan,1993, p. 34).

\section{The University}

From an organizational development perspective, potential advantages to the university as a whole are consequential (Wunsch, 1994). Although a comprehensive study is yet to be undertaken, anecdotal evidence and patterns observed by administrators point to definite improvements in organizational processes and climate. For instance, there is increased productivity by junior and senior faculty alike, as evidenced by their contributions to conference proceedings, publications, new programs, and revised courses. Such accomplishments enhance the university's reputation as a respected academic institution. 
Internally, organizational functioning has been enhanced by the feedback loops and linkages created by the proliferation of lateral and vertical communication-between academic departments, between the professoriate and professional staff, between faculty and administration, and across professorial ranks. For example, the vice president for academic affairs and assistant VPAA signal their interest and accessibility by leading a discussion of the shifting paradigm in higher education (Barr \& Tagg, 1995; Boyer, 1990; Glassick et al., 1997; Plater, 1995) and its relevance to faculty careers at MSU. Additionally, feedback from faculty has led to policy and procedural changes in the library and in the employee benefits and student advisement offices. In general, greater personal contact among people has tended to humanize the university and improve its functioning.

Perhaps the most significant institutional impact remains to be evaluated--what students gain from better teaching. Administration and faculty expect that improved classroom instruction will lead to higher student achievement levels and more meaningful learning. This hypothesis has yet to be tested, however, as the full effect of the NFP becomes apparent over time.

\section{ReCOMMENDATIONS}

\section{Enact Change Expeditiously}

More than any other factor, the key to effective new faculty development is to be vigilant about its shortcomings and to make necessary modifications as quickly as possible. This ensures a continually evolving program that is responsive to the needs of new faculty and others upon whose support the program depends. Such responsiveness is accomplished through ongoing feedback and evaluation by the new faculty and by using a preference indicator at the end of the first semester which gives them a voice in the following semester's activities. Receptivity to feedback from other parts of the university, as well, can help to establish a win-win situation that builds optimum support for the program. Flexibility should not compromise the program's integrity, however, nor interfere with its goals. Program directors should resist pressure from those who would forward their own agenda without regard for program objectives.

\section{Choose and Use Resource Faculty Well}

It is critical to select capable advisors and to use their talents wisely and to structure the program to make use of their time and expertise. If advi- 
sors feel underutilized, they may lose interest and become disengaged. Selection processes must insure that advisors are powerful teacher-scholars who are eager to share their wealth of experience in a positive way. The ideal adviser is a learner-centered, skilled facilitator who encourages the observance of group boundaries such as attendance and punctuality, keeps the group on task, and fosters productive norms and group cohesion (Gladding, 1995). At best, new faculty should experience a fully functioning group that can serve as a model for their own classrooms.

\section{Follow Developmental Guidelines}

Program design should follow fundamental principles of curriculum development and need satisfaction. A basic orientation to university structures and services should precede sessions that focus on educational theory and skill building. New faculty need to become sufficiently grounded in their new workplace before they can fully attend to complex pedagogical concepts or career planning. Instructional methods should involve the participants as actively as possible, with new faculty taking responsibility for conducting sessions themselves in later stages of the program.

\section{Attend to Amenities}

Various social and celebratory events reinforce the impression that new faculty are valued and accepted into the university community. These might include coffee service for the weekly sessions; an orientation dinner with the president, vice presidents, and deans; and socials/ receptions at the end of each semester for presenters. Such events send a message of appreciation for all those who contributed to the program throughout the year and provide another opportunity for interaction in a cordial atmosphere. Although they represent a small portion of the total cost of the program, amenities such as these help to form the bonds between people that tend to enhance the overall functioning of the university.

\section{Conclusion}

Although the particular configuration of resources and talents will vary from one institution to another, capable administrators can draw upon the unique set of assets that exist on their campuses. A well-planned program for the development of new faculty can yield rich rewards far beyond its primary purpose. Although efforts focus on the newest members of the professoriate, the synergistic effects of a successful program extend to many other campus constituencies, including students, and ultimately the academic institution itself. 


\section{REFERENCES}

Argyris, C., \& Schon, D. A. (1974). Theory and practice: Increasing professional effectiveness. San Francisco, CA: Jossey-Bass.

Barr, R., \& Tagg, J. (1995). From teaching to learning: A new paradigm for undergraduate education, Change, 27(6), 113-25.

Boice, R. (1992). The new faculty member. San Francisco, CA: Jossey-Bass.

Bollin, G., \& Hill, P. (1996). Reflections on practice. Board game developed for the Pennsylvania Society of Teaching Scholars (PASTS).

Boyer, E. L. (1990). Scholarship reconsidered: Prioritizing the professoriate. Princeton, NJ: Carnegie Foundation.

Brookfield, S. D. (1988). Developing critical thinkers. San Francisco, CA: JosseyBass.

Brookfield, S. D. (1990). The skillful teacher. San Francisco, CA: Jossey-Bass.

Deming, W. E. (1982). Quality, productivity, and competitive position. Cambridge, MA: MIT Press.

Deming, W. E. (1986). Out of the crisis. Cambridge, MA: MIT Press.

Deming, W. E. (1993). The new economics for business, government, and education. Cambridge, MA: MIT Press.

Freire, P. (1973). Education for critical consciousness. New York, NY: Continuum.

Freire, P. (1985). The politics of education: Culture, power, and liberation. South Hadley, MA: Bergin \& Garvey.

Fullan, M. (1993). Change forces: Probing the depths of educational reform. Bristol, PA: Falmer Press.

Gibb, J. R. (1978). Trust: A new view of personal and organizational development. Los Angeles, CA: The Guild of Tutors Press.

Giroux, H. A. (1983). Theory and resistance in education. New York, NY: Bergin and Garvey.

Giroux, H. A. (1988). Schooling and the struggle for public life. Minneapolis, MN: University of Minnesota Press.

Gladding, S. T. (1995). Group work: $A$ counseling specialty (2nd ed.). Englewood Cliffs, NJ: Prentice-Hall.

Glassick, C. E., Huber, M. T., \& Maeroff, G. I. (1997). Scholarship assessed: Evaluation of the professoriate. San Francisco, CA: Jossey-Bass. 
Goodlad, J. I. (1990). Teachers for our nation's schools. San Francisco, CA: JosseyBass.

Goodlad, J. I. (1994). Educational renewal. San Francisco, CA: Jossey-Bass.

Greene, M. (1986). In search of a critical pedagogy. Harvard Educational Revieze, $56(4), 427-441$.

Greene, M. (1988). The dialectic of freedom. New York, NY: Teachers College Press.

Kram, K. E. (1985). Mentoring at work. Glenview, IL: Scott, Foresman.

Meyers, C. (1988). Teaching students to think critically. San Francisco, CA: JosseyBass.

Noddings, N. (1995). Teaching themes of care, Phi Delta Kappan, 76 (9), 675-679.

Paul. R. (1990). Critical thinking. Rohnert Park, CA: Center for Critical Thinking and Moral Critique.

Plater, W. M. (1995). Future work: Faculty time in the 21 st century. Change, 27 (3), 23-33.

Rausch, E. E. (1984). Balancing needs of people and organizations: The linking elements concept. Cranford, NJ: Didactic Systems, Inc.

Schon, D. A. (1983). The reflective practitioner: How professionals think in action. New York, NY: Basic Books, Inc.

Showers, B. (1984). Peer coaching: A strategy for facilitating transfer of training. Eugene, OR: Center for Educational Policy and Management.

Wunsch, M. (Ed.). (1994). Mentoring revisited: Making an impact on individuals and institutions. San Francisco, CA: Jossey-Bass.

\section{Contact:}

Gloria Pierce

Montclair State University

College of Education and Human Services

Upper Montclair, NJ 07043

Email: PierceG@mail.montclair.edu

Gloria Pierce is Professor in the College of Education and Human Services at Montclair State University where she has been Director of the New Faculty Program since its inception in 1994. In addition to her staff development activities, she teaches courses she developed to incorporate principles of feminist therapy into the graduate program of the Department of Counseling, Human Development, and Educational Leadership. 


\section{APPENDIX 15.1 \\ Sample Schedule \\ New Faculty Program \\ Fall Semester}

September $\mathrm{x}$ Introductions and needs assessment:

Resource faculty meet with new faculty

xx Orientation tour of library services:

Library director and staff specialists

$\mathrm{xx}$ Poster session to introduce support services on campus, such as the Academic Success Center

$\mathrm{xx}$ Overview of the reappointment process: Advisement by resource faculty and recently reappointed junior faculty

October x Planning a scholarly agenda: Strategies for research and publication

$\mathrm{xx}$ Addressing issues of diversity on campus: Interactive discussion led by the dean of students

xx Local Selected Procedures Agreement and the State contract: Discussion with the dean of CEHS and a faculty union representative

xx Academic advising from a faculty perspective: Seminar led by resources faculty

November $x$ Reflections on practice: Teams of new faculty play a board game to stimulate discussion of teaching and learning

xx Faculty Scholarship Incentive Program: Discussion with the dean of SAM and a union representative

$\mathrm{xx}$ Securing external funding and internal grants other than FSIP: director of the office of research and sponsored programs

$\mathrm{xx}$ "New directions for higher education: Implications for MSU" Discussion with the VPAA and assistant VPAA

December $\mathrm{x}$ Formative evaluation of the fall semester and planning for the spring semester

$\mathrm{xx}$ Holiday celebration with president and presenters 


\section{APPENDIX 15.2 \\ SAMPLE SCHEdULE \\ New Faculty Program \\ SPRING SCHEDULE}

January $\quad x \quad$ Peer observation and coaching project (Part I): Introduce concepts and establish guidelines and partnerships

February $\quad x$ Teaching and learning session: Infusing critical thinking into the curriculum

$\mathrm{xx}$ Research and grant opportunities: External and internal sources of assistance

$\mathrm{xx}$ Teaching and learning session: Nurture and challenge in the classroom

$\mathrm{xx}$ Peer observation and coaching project (Part II): Intensive work in dyads

March $\quad x \quad$ Teaching and learning session: Assessing and grading student work

$\mathrm{xx} \quad$ Spring break

$\mathrm{xx}$ Selection of groups and topics for group-developed sessions in April

xx Teaching and learning session: The teacher-scholar-a delicate balance

$\mathrm{xx}$ Processing of peer observation and coaching project (Part III): Partners share learning with cohort

April $\quad x$ Group developed session: Teaching graduate students-methods, challenges, rewards

$\mathrm{xx}$ Group developed session: Teaching for equity-sensitivity to diversity in the classroom

xx Group developed session: Teaching with technology-computer applications to instruction

$\mathrm{xx}$ Final processing of the year's experience: Summative evaluation and recommendations for future cohorts

May $\quad x \quad$ Farewell social and reception for presenters and president 